\title{
Chemical Characterization of Oils and Fats from Amazonian Fruits by ${ }^{1} \mathrm{H}$ NMR
}

\author{
Ricardo Carvalho dos Santos 1,*, Antonio Alves de Melo Filho ${ }^{2}$, Edvan Alves Chagas ${ }^{3}$, \\ Jacqueline Aparecida Takahashi ${ }^{4}$, Ismael Fernández Montero ${ }^{5}$, Luciana Chaves Holanda ${ }^{2}$, \\ Pedro Rômulo Estevam Ribeiro ${ }^{2}$, Gabriel Franco dos Santos ${ }^{4}$ and \\ Ana Cristina Gonçalves Reis de Melo ${ }^{2}$
}

1 Post-Doctorate Program, Pro-Rector of Research and Post-Graduate, Universidade Federal de Roraima, UFRR, Campus Paricarana, CEP 69304-000, Boa Vista-RR-Brazil

2 Post-Graduate Program in Chemistry, PPGQ, Center for Research and Graduate Studies in Science and Technology, NPPGCT, Universidade Federal de Roraima, UFRR, Campus Paricarana, CEP 69304-000, Boa Vista-RR-Brazil; antonio.alves@ufrr.br (A.A.d.M.F.); lucianachavesholanda@gmail.com (L.C.H.); pedro.ribeiro@ufrr.br (P.R.E.R.); antonioalvesufrr@gmail.com (A.C.G.R.d.M.)

3 Embrapa - Brazilian Agricultural Research Corporation. Rodovia 174, Km 8, Industrial District, CEP 69301970, Boa Vista-RR-Brazil; CNPq Research Produtivity Scholarship; edvan.chagas@embrapa.br

4 Department of Chemistry, Institute of Exact Sciences, Universidade Federal de Minas Gerais, UFMG, Av Antonio Carlos, no. 6627, Pampulha, CEP 31270-901, Belo Horizonte-MG-Brazil; jat@qui.ufmg.br (J.A.T.); gfsantos@ymail.com (G.F.d.S.)

${ }^{5}$ Post Graduate Program in Biodiversity and Biotechnology, Bionorte, State Coordination of Roraima, Universidade Federal de Roraima, UFRR, Campus Cauamé, BR 174, s/n, Km 12, District Monte Cristo, CEP 69310-250, Boa Vista-RR-Brazil; ismamontero@hotmail.com

* Correspondence: ricardocs.br@gmail.com; Tel.: +55-95-98121-4145

\begin{abstract}
Native plants from the Brazilian Amazon Biome are rich in nutrientes, oils and fats and, therefore, represent a very important regional food resource. Althoung there is a global interest in the nutritional potential of tropical fruits, the potential of Amazonian fruits as source of essential fatty acids is still under exploited, since their composition is still understudied. ${ }^{1} \mathrm{H}$ Magnetic Resonance Nuclear ( ${ }^{1} \mathrm{H}$ NMR) is a robust spectroscopic tool to profile fatty acids components in oils. The objectives of this work were to use ${ }^{1} \mathrm{H}$ NMR to determine the fatty acids profile and the physicochemical properties of crude oils and fats obtained from fruits of Brazilian Amazon: açaí, ata-brava, bacaba, buriti, buritirana, murici amarelo, murici vermelho, piaçaba braba, tucumanzinho, pupunha red and yellow varieties. Oils were obtained by Soxhlet extraction using hexane as a solvent. After solvent removal by rotoevaporation, the resulting oils and fats were analyzed by ${ }^{1} \mathrm{H}$ NMR spectroscopy. Unsaturated fatty acids oleic $(\omega 9)$, linoleic $(\omega 6)$ and linolenic $(\omega 3)$ acids were quantified in the oils and their physicochemical properties were determined. It was observed that the oils have predominately $\omega 9$ fatty acids, followed by $\omega 6$ and $\omega 3$ representatives. The physicochemical properties confirmed edibility and good quality of oils and fats present in the aforementioned Amazonian fruits.
\end{abstract}

Keywords: Euterpe oleracea; Astrocaryum acaule; Mauritia aculeata; Mauritia flexuosa; PUFA; MUFA 


\section{Introduction}

Mediterranean diet is an icon of health food. This diet focuses on the abundant consumption of some fruits and vegetables along with use of olive oil as the main source of lipids. Exclusive olive oil consumption has been reported to be directly linked to lower risk of coronary artery disease [1]. Plants from Amazonian Region have a diversity of fruits like açaí [2], bacaba [3-5], buriti [6-8], pupunha $[3,9,10]$ that can be used as source of functional oils due to their high contents of phenolic compounds, as well as lipossoluble vitamins and unsaturated fatty acids. Many of these fruits present pulp and seeds rich in oils [1] containing saturated and unsaturated fatty acids with nutritional value that may comparable to ingredients of Mediterranean diet. However, the potential of Amazonian fruits as source of essential fatty acids is still under exploited.

Analysis of oil composition is traditionally carried out using chromatographic techniques such as gas chromatography (GC). Nevertheless very useful, this methodology requires hydrolysis of the triacylglycerides to release free fatty acids followed by fatty acids derivatization [11]. Complex sample handling and need of expensive derivatization agents are among the disadvantages of using GC for fatty acids analysis. Besides, sample cannot be recovered after the experiment. Fatty acids identification can also be carried out using Nuclear Magnetic Resonance (NMR), a technique that preserves oils integrity and can be used to verify authenticity and quality of oils [12]. This technique speeds up control quality process since is able to analyze the oils without need of derivatization. In addition, sample can be recovered after the experiment and data obtained enable determining physicochemical properties of the oils $[13,14]$.

The aim of this work was to determine the contents of linolenic, linoleic and oleic acids as well as some physicochemical properties, iodine index (II), acidity (AI) and saponification index (IS) of Amazonian fruit oils and fats through ${ }^{1} \mathrm{H}$ NMR spectroscopy. Fruits studied were açaí, ata brava, bacaba, buriti, buritirana, yellow murici, red murici, yellow and red pupunha, piaçava brava and tucumanzinho, shown in Figure 1. 


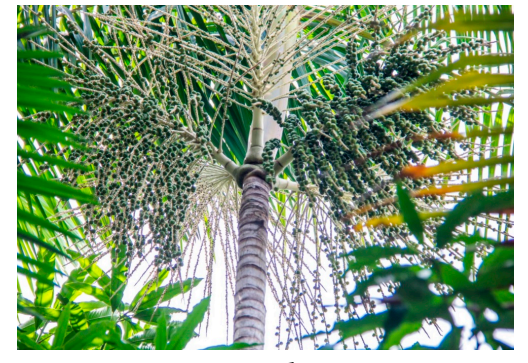

Euterpe oleracea (Açaí)

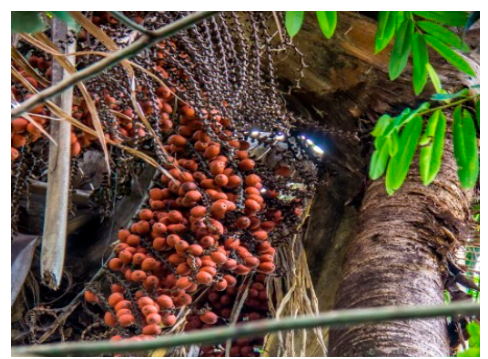

Mauritia flexuosa (Buriti)

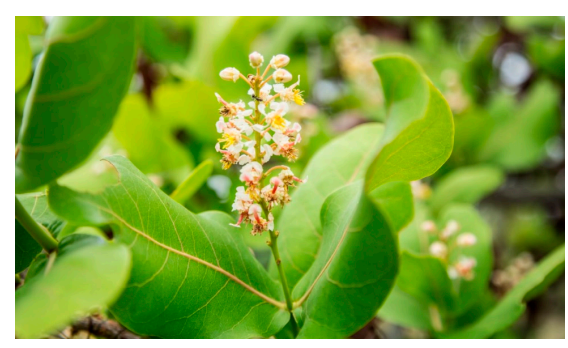

Byrsonima coccolobifolia (Red Murici)

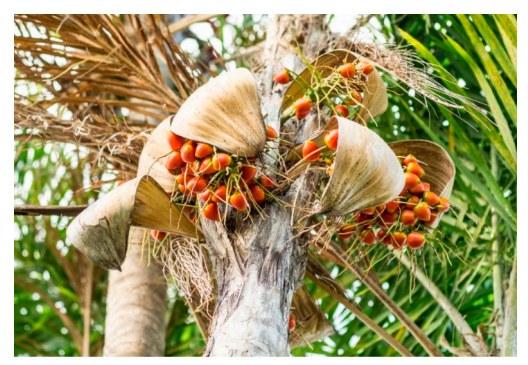

Bactris gasipaes

(Pupunha red variety)

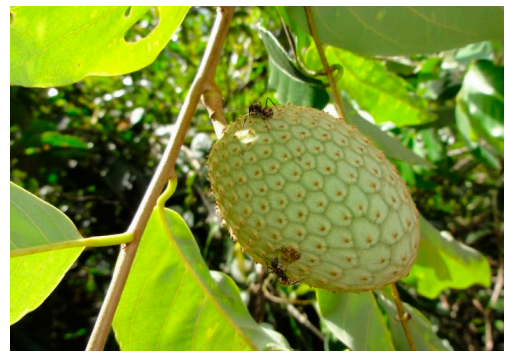

Annona hypoglauca

(Ata brava)

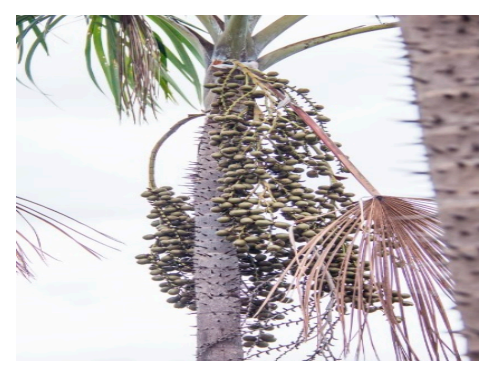

Mauritia aculeata (Buritirana)

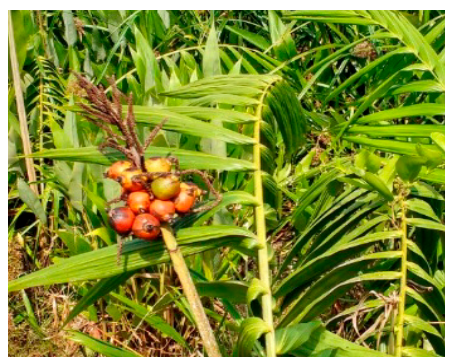

Barcella odora

(Piaçava brava)

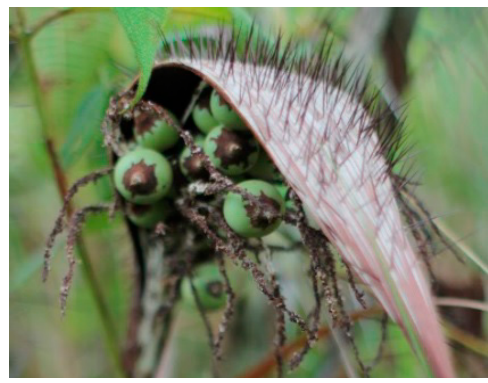

Astrocaryum acaule

(Tucumanzinho)

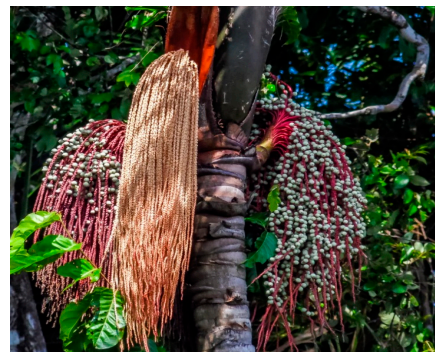

Oenocarpus bacaba (Bacaba)

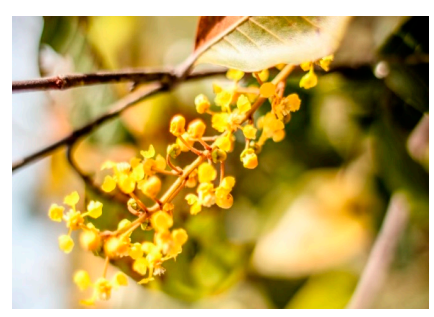

Byrsonima crassifolia (Yellow Murici)

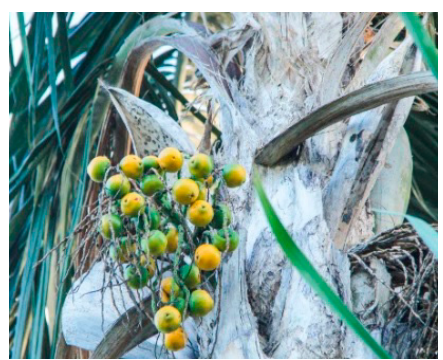

Bactris gasipaes

(Pupunha yellow variety)

Figure 1. Amazonian fruits in Roraima state, Brazil (Pictures by R.C. Santos). 


\section{Results}

All ${ }^{1} \mathrm{H}$ NMR spectra obtained for the oils can be found as Supplementary Materials (Figures S1-S10), except the spectrum of Piaçava brava oil, shown below (Figure 2).

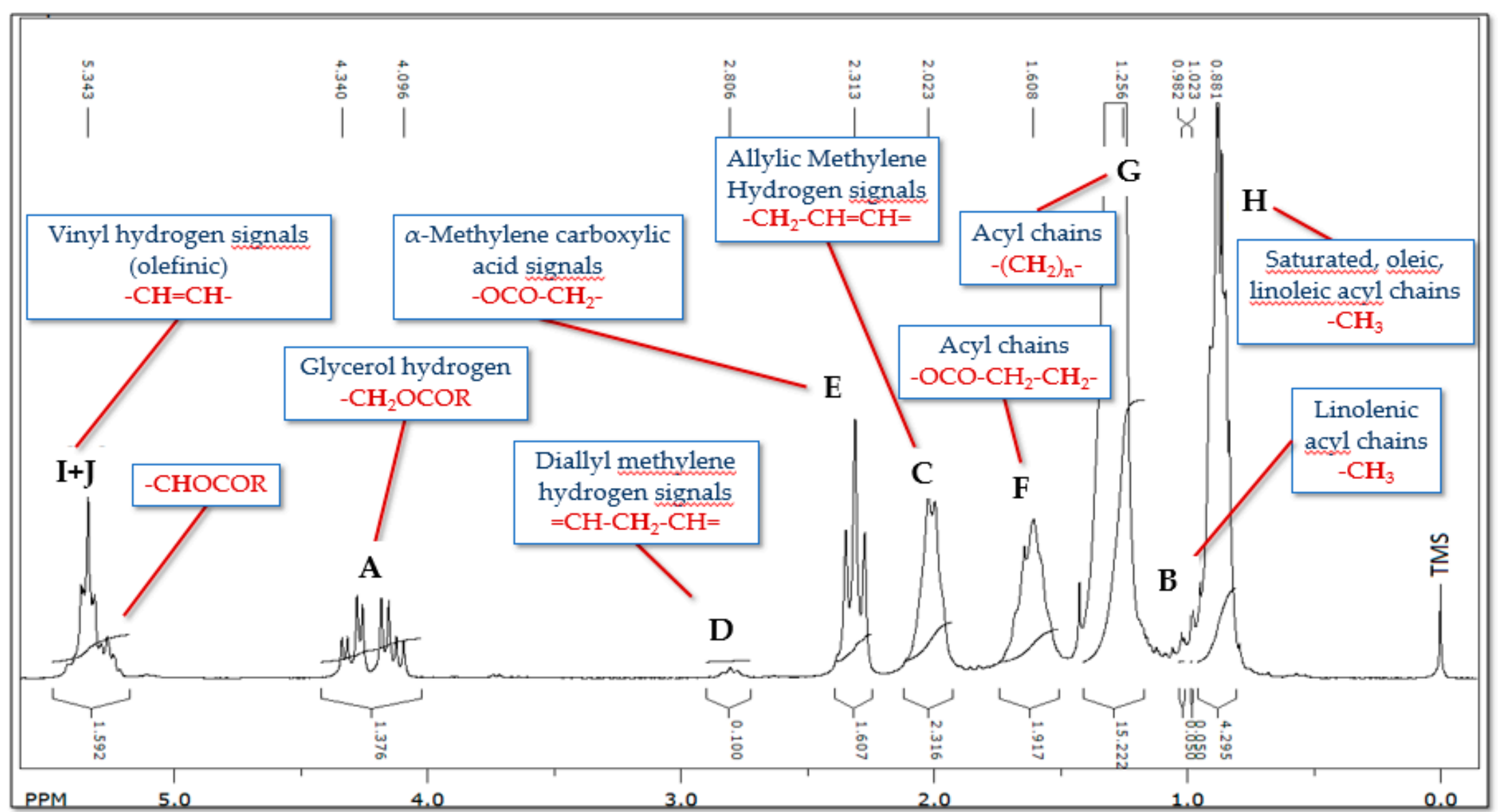

Figure 2. ${ }^{1} \mathrm{H}$ NMR spectrum from Piaçava brava oil in the region of 0-5.5 ppm $\left(200 \mathrm{MHz}, \mathrm{CDCl}_{3}\right)$. 
The major components of the oils present in the respective ${ }^{1} \mathrm{H}$ NMR spectra were used to quantify the amounts of linolenic, linoleic and oleic acids ( $\omega 3$, $\omega 6$ and $\omega 9$, respectively) and to determine some physicochemical properties of such oils. The results are shown in Table 1.

Table 1. Linolenic, linoleic and oleic acids contents and physicochemical properties of oils present in Amazonian fruits as determined by ${ }^{1} \mathrm{H}$ NMR.

\begin{tabular}{|c|c|c|c|c|c|c|c|c|c|}
\hline \multirow{2}{*}{$\begin{array}{l}\text { Amazonian } \\
\text { fruits }\end{array}$} & \multirow{2}{*}{$\begin{array}{l}\text { Spectrum } \\
\text { number }\end{array}$} & \multicolumn{3}{|c|}{ Concentration $(\%)$} & \multicolumn{5}{|c|}{ Physicochemical properties } \\
\hline & & $\omega 3$ & $\omega 6$ & $\omega 9$ & $\begin{array}{c}\text { II } \\
\left(\mathrm{g} \mathrm{I}_{2} 100 \mathrm{~g}^{-1}\right)\end{array}$ & $\begin{array}{c}\mathrm{AI} \\
\left(\mathrm{mg} \mathrm{KOH} \mathrm{g}^{-1}\right)\end{array}$ & $\begin{array}{c}\mathrm{SI} \\
\left(\mathrm{mg} \mathrm{KOH} \mathrm{g}^{-1}\right)\end{array}$ & $\begin{array}{c}\mathrm{MM} \\
\left(\mathrm{g} \mathrm{mol}^{-1}\right)\end{array}$ & $\mathbf{R}_{\mathbf{o}, \mathbf{a}}$ \\
\hline Ata brava & S1 & 0.65 & 29.45 & 43.21 & 89.60 & 0.14 & 177.34 & 937.58 & 1.18 \\
\hline Açaí & S2 & 0.8 & 7.8 & 65.2 & 78.55 & 0.16 & 175.34 & 901.21 & 1.14 \\
\hline Bacaba & S3 & 0.56 & 4.33 & 44.78 & 63.62 & 0.19 & 212.67 & 787.73 & 0.84 \\
\hline Buriti & S4 & 1.00 & 2.91 & 67.14 & 71.85 & 0.10 & 206.62 & 813.42 & 0.94 \\
\hline Buritirana & S5 & 1.4 & 1.8 & 69.4 & 81.10 & 0.15 & 178.79 & 858.09 & 0.89 \\
\hline Yellow Murici & S6 & 0.31 & 29.89 & 38.07 & 90.27 & 0.15 & 207.68 & 808.89 & 1.19 \\
\hline Red Murici & S7 & 0.51 & 29.51 & 33.59 & 85.22 & 0.10 & 212.39 & 788.94 & 1.12 \\
\hline Piaçaba brava & Figure 2 & 1.62 & 1.60 & 52.88 & 63.62 & 0.19 & 227.76 & 723.73 & 0.84 \\
\hline Yellow Pupunha & S8 & 0.60 & 4.89 & 38.37 & 33.74 & 0.22 & 244.99 & 650.67 & 0.71 \\
\hline Red Pupunha & S9 & 2.44 & 10.66 & 26.18 & 70.47 & 0.12 & 168.63 & 974.50 & 0.91 \\
\hline Tucumanzinho & S10 & 0.67 & 2.61 & 75.38 & 84.24 & 0.09 & 178.24 & 956.65 & 1.10 \\
\hline
\end{tabular}

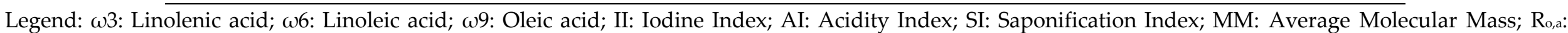
Olefinic/aliphatic Ratio. S1-S10: Supplementary materials are figures referring to the spectrum of each sample. 
Oleic acid is an unsaturated fatty acid $(\omega 9)$ and characteristic signals of its structure observed in the oils ${ }^{1} \mathrm{H}$ NMR spectra (Supplementary materials: Figures S1-S10) are in accordance with data described in the literature [15]. The contents of this acid, as estimated by the evaluation of corresponding signals in the NMR spectra of the oils analyzed, varied between 26.18\% (Red Pupunha) to $75.38 \%$ (Tucumanzinho) in samples studied (Table 1). This variation in oleic acid content, observed for oils of Amazonian fruits, was also observed for non-Amazonian fruit oils as reported by Guillén and Ruiz (2003) [15]. Concentration of $\omega 9$ in tucumanzinho oil is comparable to the average concentration of olives residue oil (76\%) and slightly lower than the average concentrations of monounsaturated extra virgin olive $(80.8 \%)$, olive $(79.4 \%)$, nut virgin $(82.4 \%)$ and refined $(78.1 \%)$ oils.

The benefits of oleic acid are reported to be associated to synergy with other components obtained from the diet when there is frequent consumption of olive oil (rich in oleic acid), fish (rich in linolenic acid) and red wine (or olives) (rich in polyphenols) [16, 17]. In addition, a great highlight is given to the presence of oleic acid in the diet, as it has been associated to beneficial effects on cancer [18], autoimmune [18] and rheumatic diseases [19], anti-inflammatory [20], beneficial effects on diabetes mellitus [21], reduction of coronary heart disease [16], among others. Lipidic macromolecules can be fragmented by the action of bile and pancreatic secretions, entering into the bloodstream [22]

Signals for linoleic acid [15], a polyunsaturated fatty acid ( $\omega 6)$ were detected in the ${ }^{1} \mathrm{H}$ NMR spectra obtained for the Amazonian oils (Figure 2 and S1-S10). Regarding to the contents of this component, the Amazonian fruits studied were classified in three groups: the first one, comprising samples with low yields of this fatty acid (bacaba, buriti, buritirana, piaçaba brava, yellow pupunha and tucumazinho (values lower than $4.89 \%$ ). The second class, with two representants, açai (7.8\%) and red pupunha $(10.66 \%)$, with intermediate contents, and the third class, with the fruits with the most expressive amounts of linoleic acid: ata brava (29.45\%), yellow murici (29.89\%), and red murici (29.81).

The main importance of linoleic acid consumption relies in the reduction of cardiovascular risks. According to Poli and Visioli (2015) [23] the bigger consumption of $\omega 6$ fatty acids, the lower are the risks of cardiovascular diseases. Besides, linoleic acid has bioactivity on dermatitis and eczema, rheumatoid arthritis, premenstrual syndrome and prevention of stroke [24].

Regarding to the presence of linolenic acid ( $\omega 3)$ in the fruits studied, contents varied from 0.31 (yellow murici) to $2.44 \%$ (red pupunha) (Table 1). Low contents of oleic acid is common in several oils of vegetal origin [15], except for canola, soya, nuts and linseed. Simopoulos (2004) [25] cites a series of benefits attributed to $\omega 3$ fatty acids in the treatment of hypertension, diabetes, arthritis, coronary, autoimmune, inflammatory diseases among others.

Linoleic and linolenic acids are essential to human metabolism and must be obtained from the diet, since humans cannot endogenously synthesize them [26]. However, intake must be done in a balanced manner and so that the ingestion of $\omega 6$ is not very high, since excess is associated with cardiovascular and other diseases [27]. For this reason, FAO (2010) [28] recommends ingestion of $\omega-6$ between $2.5-9 \%$ and $\omega 3$ between $0.5-2 \%$. Appropriate consumption of those fatty acids helps regulating the inflammatory process, oxidative stress and endothelial function [29].

Contents of unsaturated in the oils were confirmed by determining their iodine index (II), a parameter used to express the degree of unsaturation and the proportion of different acyl groups in the samples (Table 1). Levels of oleic, linoleic and linolenic acids found in the oils studied are in accordance with contents reported for non-Amazonian oils [15], as for linseed (183.1 g I2 $\left.100 \mathrm{~g}^{-1}\right)$, which is rich in linolenic acid (three unsaturations). For soy oil, the value reported for II is lower (127.6-129.9 $\mathrm{g} \mathrm{I}_{2} 100 \mathrm{~g}^{-1}$ ), which is compatible with its major constituent (linoleic acid, two unsaturations). For olive oil, iodine index is lower (77.4-80.7 $\mathrm{g} \mathrm{I}_{2} 100 \mathrm{~g}^{-1}$ ) since it is richer in the monounsaturated oleic acid.

$R_{o, a}$ values (Table 1 ) of the Amazonian oils studied varied from 0.71 to 1.19 , and are in accordance with data reported for vegetable oils, in which this value should not be inferior to 0.66 [30]. In this way, the values found in this work indicate that the fruits, already consumed in Roraima state (Brazil) are indeed adequate for human consumption. Carneiro, Reda and Carneiro 
(2005) [30] report that this property can be used to measure the degree of unsaturation present in oils and fats, in addition to indicating the oxidation state of samples, the latter with more precision than the peroxide index.

Acidity index indicates the good quality in obtaining and handling the oil, as well as oil degradation and adulterated, so the value assigned to the index should be inferior than or equal to $0.8 \%$ for olive oils extra virgin. All values found(Table 1) are below this value [31].

In the saponification index, it is observed that the crude oils from the Amazon (Table 1) are in consonance, since the saponification index is inversely proportional to the average molecular weight of the fat (MW). This index is used to observe the size of the fatty acid chain [30].

Therefore, all of the physicochemical parameters determined by ${ }^{1} \mathrm{H}$ NMR indicated the quality of the edible oils and fats present in the fruits studied, and can be used to detect adulteration or oxidation. In addition this is a fast, practical and non-destructive technique for oils indentification.

\section{Materials and Methods}

\subsection{Samples preparation and oil obtaining}

The fruits screened in this work açaí (pulp), ata brava (seeds), bacaba (green fruits pulp), buriti (pulp), buritirana (pulp), yellow murici (seeds), red murici (seeds), piaçaba braba (pulp), tucumanzinho (pulp), red (pulp) and yellow pupunha (pulp) were obtained in different regions and in the market from Roraima State, Brazil.

The seeds and pulps were dried in an oven with circulating air at $50{ }^{\circ} \mathrm{C}$ for $48 \mathrm{~h}$ to remove the moisture. Then, the plant materials were milled and sieved (20-40 Mesh), for obtaining a homogenized powder that was extracted from hexane in a Soxhlet Extractor, to obtain the raw oils and fats. Solvent was removed on a rotoevaporador, the extracts were placed in amber bottles under nitrogen atmosphere until further analysis [32].

\section{2. ${ }^{1} \mathrm{H}$ Nuclear Magnetic Resonance (NMR) Spectroscopy}

${ }^{1} \mathrm{H}$ NMR spectra were recorded on a Bruker Avance DPX 200 spectrometer, operating 4.7 Tesla, corresponding to the resonance frequency of $200.13 \mathrm{MHz}$ for the ${ }^{1} \mathrm{H}$ core, equipped with a direct detection probe head operating at $300 \mathrm{~K}$. The samples were analyzed in $5 \mathrm{~mm}$ NMR tubes Wilmad ${ }^{\circledR}$. NMR samples were prepared by dissolution of $0.5 \mathrm{~mL}$ of each oil in $0.6 \mathrm{~mL}$ of $\mathrm{CDCl}_{3}$. Chemical shifts are presented in ppm, using TMS as internal standard.

\section{3. ${ }^{1} \mathrm{H} N \mathrm{NMR}$ spectra analyses}

${ }^{1} \mathrm{H}$ NMR spectra of samples were processed in the software SpinWorks 4.2 [33]. Chemical shifts were analyzed according to Guillén and Ruiz (2003) [15] for non-Amazon fruits. The chemical shifts showed signs characteristic of the fatty acids before mentioned, and were used to calculate their physical properties. The following mathematical equations used to determine the amount in $\%$ of omegas 3, 6 and 9, as well as the physicochemical properties.

\subsubsection{Determination of percent amount of omega $3(\omega 3), 6(\omega 6)$ and $9(\omega 9)$}

To quantify the concentration of unsaturated fatty acids oleic, linoleic and linolenic acids according to the equations proposed by Garcia (2006) [34]. Calculi of percent amounts of $\omega 3$ (18:3), $\omega 6$ (18:2) and $\omega 9$ (18:1) of fatty acids, in Amazon fruits oils, were obtained based on characteristic NMR signals found in the ${ }^{1} \mathrm{H}$ NMR spectra and named A, B, C and D (Figure 2 and Supplementary materials: Figures S1-S10) according to methodology proposed in the literature [34].

Percentage of $\omega 3$ (18:3) (\%): [(B/A)/2.25].100

where A: Glycerol hydrogen; B: Linolenic acid; 2.25: Maximum theoretical ratio of trilinolenin [34]

Percentage of $\omega 6$ (18:2) (\%): $\mathrm{D}=\mathrm{D}_{18: 3}+\mathrm{D}_{18: 2 \mathrm{R}} \mathrm{D}_{18: 3} / \mathrm{A}=\left[(\% 18: 3)^{*} 3\right] / 100$

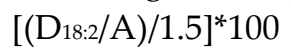

where D: Bis-allyl; 1.5: Maximum theoretical ratio of trilinolein [34] 
Percentage of $\omega 9(18: 1)(\%): C=C_{18: 3}+C_{18: 2}+C_{18: 1}$

$\mathrm{RD} 18: 3 / \mathrm{A}=\left[(\% 18: 3)^{*}\right] / 100$

$\mathrm{D}_{18: 3}=(\mathrm{RD} 18: 3 / \mathrm{A})^{*} \mathrm{ARC} \mathrm{C}_{18: 2} / \mathrm{A}=[(\% 18: 2) * 3] / 100$

$\mathrm{C}_{18: 2}=\left(\mathrm{RC}_{18: 2} / \mathrm{A}\right)^{*} \mathrm{~A}$

$\mathrm{C}_{18: 3}+\mathrm{C}_{18: 2}+\mathrm{C}_{18: 1}$

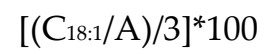

Where C: Allylic hydrogen; 3: Maximum theoretical ratio of triolein [34]

\subsubsection{Physicochemical Properties}

The physicochemical properties according to the equations proposed by Carneiro, Reda and Carneiro (2005) [30] and Garcia (2006) [34], as Iodine Index (II), Saponification Index (SI), Acidity Index (AI) and Proportion of olefinic/aliphatic hydrogen atoms ( $\mathrm{R}_{\mathrm{o}, \mathrm{a}}$ ). In the following equations, $\mathrm{A}$, $\mathrm{B}, \mathrm{C} \ldots$, and $\mathrm{K}$ correspond to the value of the integral of the corresponding signal in the NMR spectra.

\subsubsection{Iodine Index (II)}

From the data provided in the ${ }^{1} \mathrm{H}$ NMR spectra it was possible to calculate the molecular weight (MW) $\left(\mathrm{g} \mathrm{mol}^{-1}\right)$ and thus the iodine index. The iodine index parameter indicates the presence of double bonds in oils and fats, and may be expressed in grams of iodine which will react with the double bonds in 100 grams of sample ( $\mathrm{g} \mathrm{I}_{2} 100 \mathrm{~g}^{-1}$ ):

$$
\mathrm{II}=\frac{126.91 \times 100 \times \mathrm{V}}{\mathrm{MW}}
$$

Where the value of 126.91 is related to the atomic mass of iodine; V corresponds to the vinyl protons and can be calculated using equation 2 :

$$
V=\frac{\left(J+R^{2}\right)-A p}{A p}
$$

Where Ap corresponds to the integral of one hydrogen and is calculated using equation 3 :

$$
\mathrm{Ap}=\frac{(\mathrm{I}+\mathrm{H})}{4}
$$

\subsubsection{Saponification Index (SI)}

The saponification index represents the number of milligrams of potassium hydroxide per gram of Amazonian oil (mg KOH g-1):

$$
\begin{gathered}
\text { SI }=[\text { MW } \times(-0.2358)]+398.42 \\
\text { MW }-110.7+(7.036 \times \mathrm{T})+(5.983 \times V) \\
\mathrm{T}\left(\text { Total hydrogem arsa) }=\frac{(\mathrm{I}+\mathrm{D}+\mathrm{A}+\mathrm{B}+\mathrm{D}+\mathrm{B}+\mathrm{C}+\mathrm{F}+\mathrm{G}+(\mathrm{B}+\mathrm{H})}{\mathrm{Ap}}\right.
\end{gathered}
$$

Where the value of 398.42 is relative to the average mass of the fatty acids.

\subsubsection{Acidity Index (AI)}

This parameter is calculated in order to get the acidity index of vegetable oils. This parameter also indicates the degree of unsaturation and oxidative condition of the oil, being more accurate than the peroxide index [30].

$$
A I=3.0597 \times\left(R_{8,2}\right)^{2}-6.3181 \times\left(R_{\mathrm{v}, 2}\right)+3.3381
$$

\subsubsection{Proportion between olefinic and aliphatic hydrogen atoms $\left(R_{0, a}\right)$}

The $\mathrm{R}_{\mathrm{o}, \mathrm{a}}$ property verifies the ratio of olefinic to aliphatic hydrogen atoms, so it can be used to measure the degree of unsaturation present in oils and fats, in addition to indicating the oxidation of samples: 


$$
\mathrm{R}_{\mathrm{o}, \mathrm{a}}=\frac{\mathrm{v}}{\mathrm{A}+\mathrm{B}}
$$

\section{Conclusions}

The Amazonian crude oils and fats herein studied presented high concentrations of $\omega 9$ fatty acids, followed by small concentrations of $\omega 3$ and $\omega 6$. Tucumanzinho presented $\omega 9$ contents close to that of olive oil, indicating that this oil can offer many benefits to the human health. As for the physical-chemical characterization, all samples are within the allowed values for human consumption.

This study shows that Amazonian biodiversity is able to provide fruits with essential fatty acids. This knowledge may contribute to the popularization of the consumption of exotic fruits, as part of a heath diet or as components of novel gastronomic dishes inspired in healthy fruits.

Acknowledgments: To CAPES for the scholarship and to FAPEMIG for financial support.

Author Contributions: R.C.S. performed the experiments, analyzed the data, wrote the paper; E.A.C. performed the experiments, contributed reagents/materials/analysis tools; A.A.M.F. performed the experiments, analyzed the data; J.A.T. performed the experiments, contributed reagents/materials/analysis tools; I.F.M., L.C.H., L.C.H., P.E. R.R., G.F.S. and A.C.G.R.M. performed the experiments.

Conflicts of Interest: These authors declare no conflicts of interest.

\section{References}

1. Dimitriou, M.; Rallidis, L.S.; Theodoraki, E.V.; Kalafati, I.P.; Kolovou, G.; Dedoussis, G.V. Exclusive olive oil consumption has a protective effect on coronary artery disease; overview of the THISEAS study. Public Health Nutr. 2016, 19, 1081-1087. [CrossRef] [PubMed]

2. Yamaguchi, K.K.L.; Pereira, L.F.R.; Lamarão, C.V.; Lima, E.S.; Veiga-Junior, V.F. Amazon acai: Chemistry and biological activities: A review. Food Chem. 2015, 179, 137-151. [CrossRef] [ㅁubMed]

3. Dos Santos, M. F.G.; Alves, R.E.; Brito, E.S.; Silva, S.M.; Silveira, M.R.S. Quality characteristis of fruits and oils of palms native to the brazilian amazon. Rev. Bras. Frutic. 2017, 39, 1-6. [CrossRef]

4. Neves, L.T.B.C.; Campos, D.C.S.; Mendes, J.K.S.; Urnhani, C.O.; Araújo, K.G.M. Qualidade de frutos processados artesanalmente de açaí (Euterpe oleracea Mart.) e Bacaba (Oenocarpus bacaba MART.). Rev. Bras. Frutic. 2015, 37, 729-738. [CrossRef]

5. Abadio Finco, F.D.; Kammerer, D.R.; Carle, R.; Tseng, W.H.; Böser, S.; Graeve, L. Antioxidant activity and characterization of phenolic compounds from bacaba (Oenocarpus bacaba Mart.) fruit by HPLC-DAD-MS(n). J. Agric. Food Chem. 2012, 8; 7665-73. [CrossRef] [PubMed]

6. Koolen, H.H.F.; da Silva, F.M.A.; Gozzo, F.C.; de Souza, A.Q.L.; de Souza, A.D.L. Antioxidant, antimicrobial activities and characterization of phenolic compounds from buriti (Mauritia flexuosa L. f.) by UPLC-ESI-MS/MS. Food Res. Int. 2013, 51, 467-473. [CrossRef]

7. Silva, S.M.; Rocco, S.A.; Sampaio, K.A.; Taham, T.; da Silva, L.H.M.; Ceriani, R.; Meirelles, A.J.A. Validation of a method for simultaneous quantification of total carotenes and tocols in vegetable oils by HPL. Food Chem. 2011, 129, 1874-1881. [CrossRef]

8. Manhães, L.R.T.; Sabaa-Srur, A.U.O. Centesimal composition and bioactive compounds in fruits of buriti collected in Pará. Ciênc. Tecnol. Aliment. 2011, 31, 856-863. [CrossRef]

9. Rojas-Garbanzo, C.; Pérez, A.M.; Vaillant, F.; Pineda-Castro, M.L. Physicochemical and antioxidant composition of fresh peach palm (Bactris gasipaes Kunth) fruits in Costa Rica. Braz. J. Food Technol. 2016, 19, 1-9. [CrossRef]

10. Yuyama, L.K.O.; Yonekura, L.; Aguiar, J.P.L.; Sousa, R.F.S. Biodisponibilidade de vitamina a da pupunha (Bactris gasipaes Kunth) em Ratos. Acta Amaz. 1999, 29, 497-500. [CrossRef]

11. Fernandez, I.M.; Mozombite, D.M.S.; Santos, R.C; Melo Filho, A.A.; Ribeiro, P.R.E.; Chagas, E.A.; Takahashi, J.A.; Ferraz, V.P.; Melo, A.C.G.R.; Maldonado, S.A.S. Oil in inajá pulp (Maximiliana maripa): Fatty acid profile and anti-acetylcholinesterase activity. Orbital: Electron. J. Chem. 2016, 8, 80-83. [CrossRef] 
12. Salinero, C.; Feás, X.; Mansilla, J.P.; Seijas, J.A.; Vázquez-Tato, M.P.; Vela, P.; Sainz, M.J. ${ }^{1} H-N u c l e a r$ Magnetic Resonance analysis of the triacylglyceride composition of cold-pressed oil from Camellia japonica. Molecules, 2012, 17, 6716-6727. [CrossRef] [uuMed]

13. Vigli, G.; Philippidis, A.; Spyros, A.; Dais, P. Classification of edible oils by employing $31 \mathrm{P}$ and ${ }^{1} \mathrm{H}$ NMR spectroscopy in combination with multivariate statistical analysis. A proposal for the detection of seed oil adulteration in virgin olive oils. J. Agr. Food Chem. 2003, 51, 5715-5722. [CrossRef] [PubMed]

14. Knothe, G.; Kenar, J.A. Determination of the fatty acid profile by ${ }^{1} \mathrm{H}-\mathrm{NMR}$ spectroscopy. Eur. J. Lipid Sci. Tech. 2004, 106, 88-96. [CrossRef]

15. Guillén, M. D.; Ruiz, A. Rapid simultaneous determination by proton NMR of unsaturation and composition of acyl groups in vegetable oils. Eur. J. Lipid Sci. Tech. 2003, 105, 688-696. [CrossRef]

16. Lou-Bonafonte, J.M.; Fitó, M.; Covas, M.-I.; Farràs, M.; Osada, J. HDL-Related mechanisms of olive oil protection in cardiovascular disease. Curr. Vasc. Pharmacol. 2012, 10, 392-409. [CrossRef] [PubMed]

17. Pauwels, E.K.J. The Protective effect of the mediterranean diet: Focus on cancer and cardiovascular risk. Med. Princ. Pract. 2011, 20, 103-111. [CrossRef] [PubMed]

18. Sales-Campos, H.; Souza, P.R.; Peghini, B.C.; Silva, J.S.; Cardoso, C.R. An overview of the modulatory effects of oleic acid in health and disease. Mini Rev. Med. Chem. 2013, 13, 201-10. [CrossRef]

19. Sales, C.; Oliviero, F.; Spinella, P. The mediterranean diet model in inflammatory rheumatic diseases. Reumatismo, 2009, 61, 10-14. [PubMed]

20. Carrillo, C.; Cavia, M.M.; Alonso-Torre, S. Role of oleic acid in immune system; mechanism of action; a review. Nutr. Hosp. 2012, 27, 978-990. [PubMed]

21. Vassiliou, E.K.; Gonzalez, A.; Garcia, C.; Tadros, J.H.; Chakraborty, G.; Toney, J.H. Oleic acid and peanut oil high in oleic acid reverse the inhibitory effect of insulin production of the inflammatory cytokine TNF- $\alpha$ both in vitro and in vivo systems. Lipids Health Dis. 2009, 8, 1-10. [CrossRef] [PubMed]

22. Barrett, K.E.; Barman, S.M.; Boitano, S.; Brooks, H.L. Ganong's review of medical physiology, 24th ed.; McGraw-Hill Medical: New York, 2012; pp. 429-449.

23. Poli, A.; Visioli, F. Recent evidence on omega 6 fatty acids and cardiovascular risk. Eur. J. Lipid Sci. Tech. 2015, 117, 1847-1852. [CrossRef]

24. Knowles, J.; Watkinson, C. Extraction of omega-6 fatty acids from speciality seeds. Lipid Technol. 2014, 26, 107-110. [CrossRef]

25. Simopoulos, A.P. Omega-3 fatty acids and antioxidants in edible wild plants. Biol. Res. 2004, 37, 263-277. [CrossRef] [리Med]

26. Zivkovic, A.M.; Telis, N.; German, J.B.; Hammock, B.D. Dietary omega-3 fatty acids aid in the modulation of inflammation and metabolic health. Calif. Agric. 2011, 65, 106-111. [CrossRef] [PubMed]

27. Simopoulos, A.P. Evolutionary aspects of diet, the omega-6/omega-3 ratio and genetic variation: nutritional implications for chronic diseases. Biomed. Pharmacother. 2006, 60, 502-507. [CrossRef] [PubMed]

28. FAO. Food and Agriculture Organization of the United Nations. Fats and fatty acids in human nutrition Report of na expert consultation. FAO Food and Nutrition Paper n. 91, 2008. Geneva: FAO, 2010. 180 p. Available online: http://www.fao.org/3/a-i1953e.pdf (Access on 05 January 2016).

29. Yang, L.G.; Song, Z.X.; Yin, H.; Wang, Y.Y.; Shu, G.F.; Lu, H.X.; Wang, S.K.; Sun, G.J. Low n-6/n-3 PUFA ratio improves lipid metabolism, inflammation, oxidative stress and endothelial function in rats using plant oils as n-3 fatty acid source. Lipids, 2015, 51, 49-59. [CrossRef] [PubMed]

30. Carneiro, P.I.B.; Reda, S.Y.; Carneiro, E.B.B. ${ }^{1} \mathrm{H}$ NMR Characterization of seed oils from Rangpur Lime (Citrus limonia) and "Sicilian" Lemon (Citrus limon). Ann. Magn. Reson. 2005, 4, 64-68.

31. Mailer, R.; Beckingham, C. Testing olive oil quality: chemical and sensory methods. Primefact NSW DPI, 2006, 231, 1-5.

32. Santos, R.C.; Melo Filho, A.A.; Chagas, E.A.; Takahashi, J.A.; Ferraz, V.P.; Costa, A.K.; Melo, A.C.G.R.; Montero, I.F.; Ribeiro, P.R.E. Fatty acid profile and bioactivity from Annona hypoglauca seeds oil. Afr. J. Biotechnol. 2015, 14, 30. [CrossRef]

33. SpinWorks Version 4.2.0, 2015. Kirk Marat, University of Manitoba.

34. Garcia, C.M. Transesterificação de óleos vegetais. 2006. 136 p. Dissertação (Mestrado em Química) Instituto de Química, Universidade Estadual de Campinas, Unicamp. Campinhas, São Paulo: 2006.

Sample Availability: Samples of the compounds ...... are available from the authors. 
Supplementary Materials $-{ }^{1} \mathrm{H}$ NMR spectra $\left(200 \mathrm{MHz}, \mathrm{CDCl}_{3}\right)$ of Amazonian oils

Figure S1. Açaí (Euterpe oleracea)

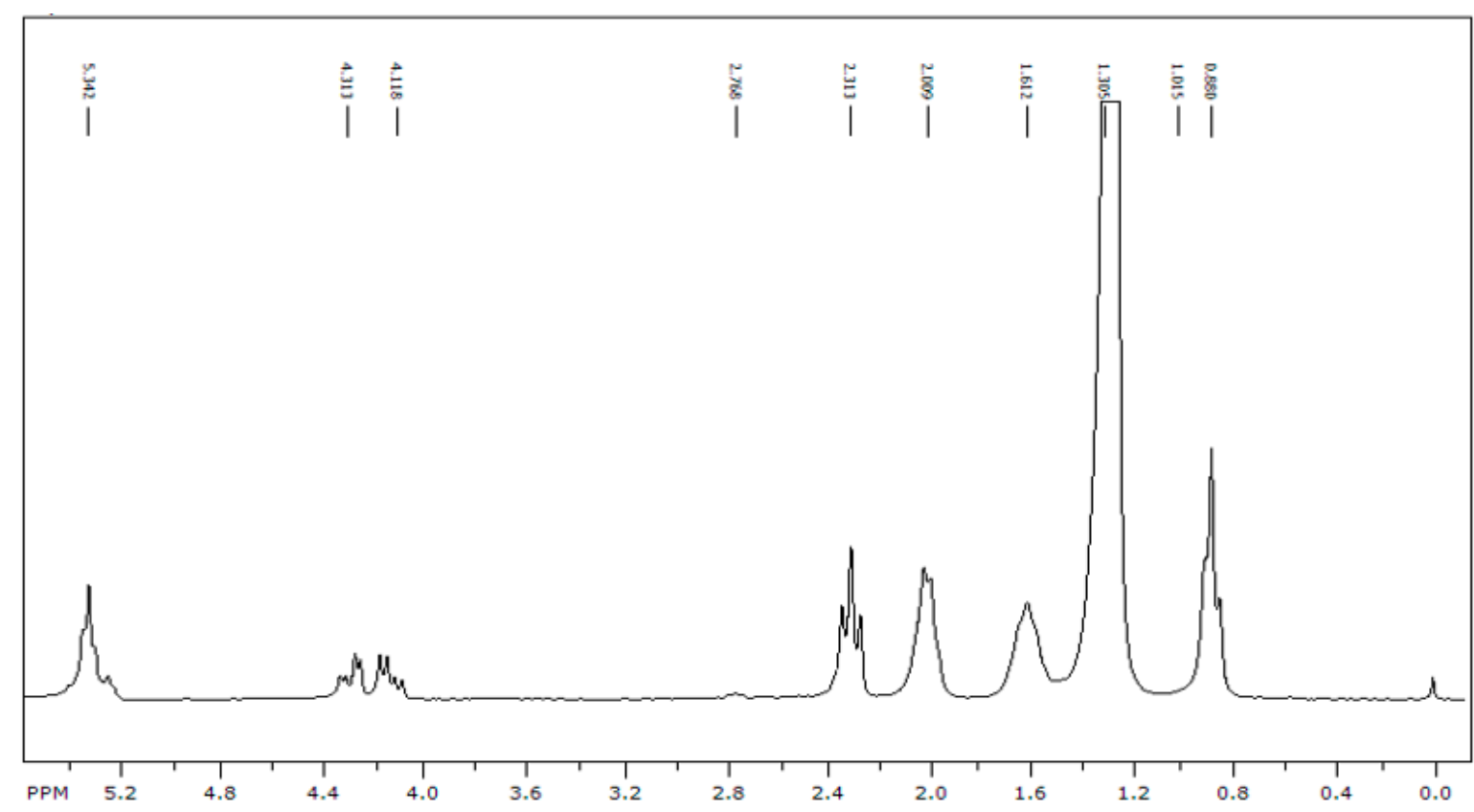

Figure S2. Ata Brava (Annona hypoglauca)

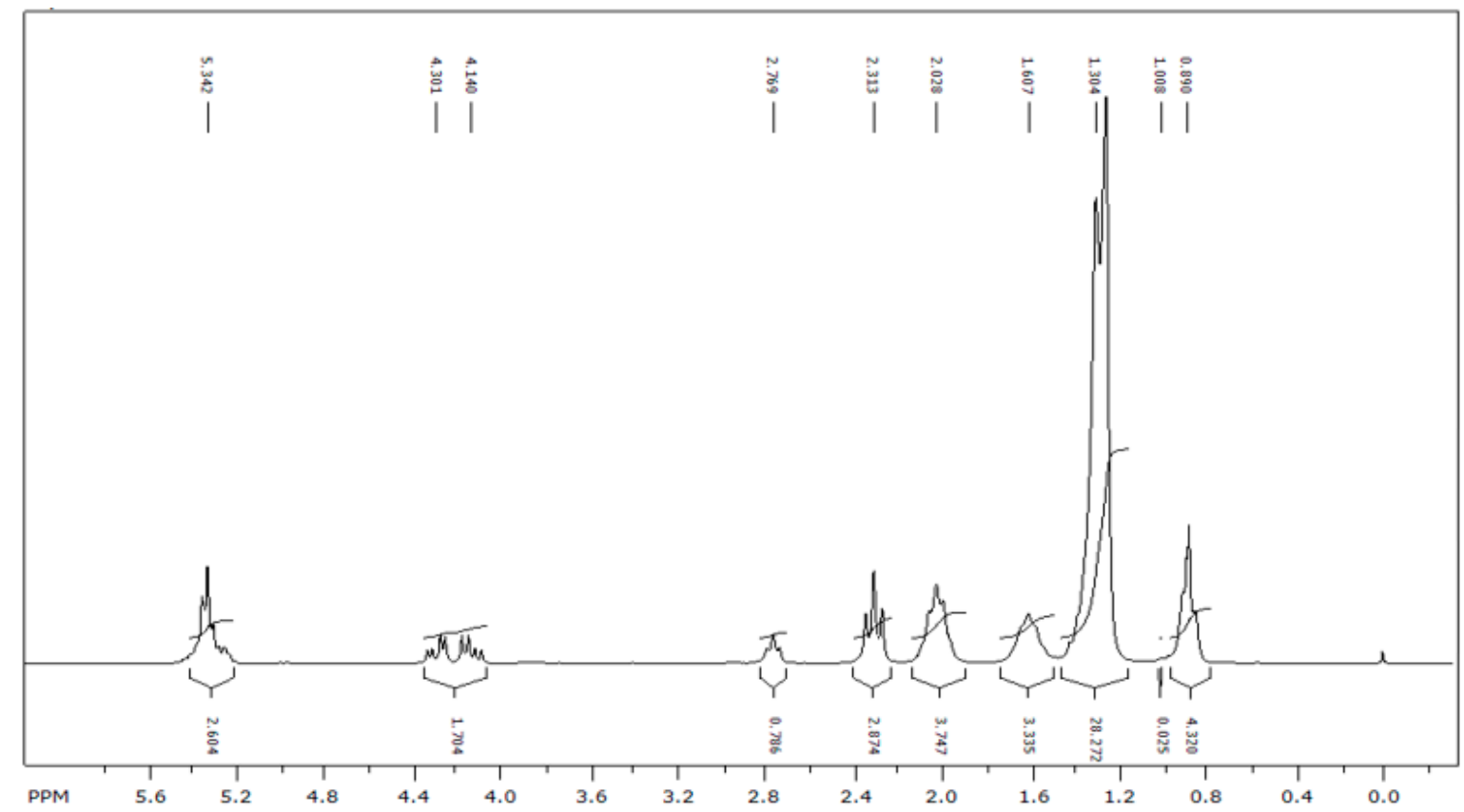


Figure S3. Bacaba (Oenocarpus bacaba)

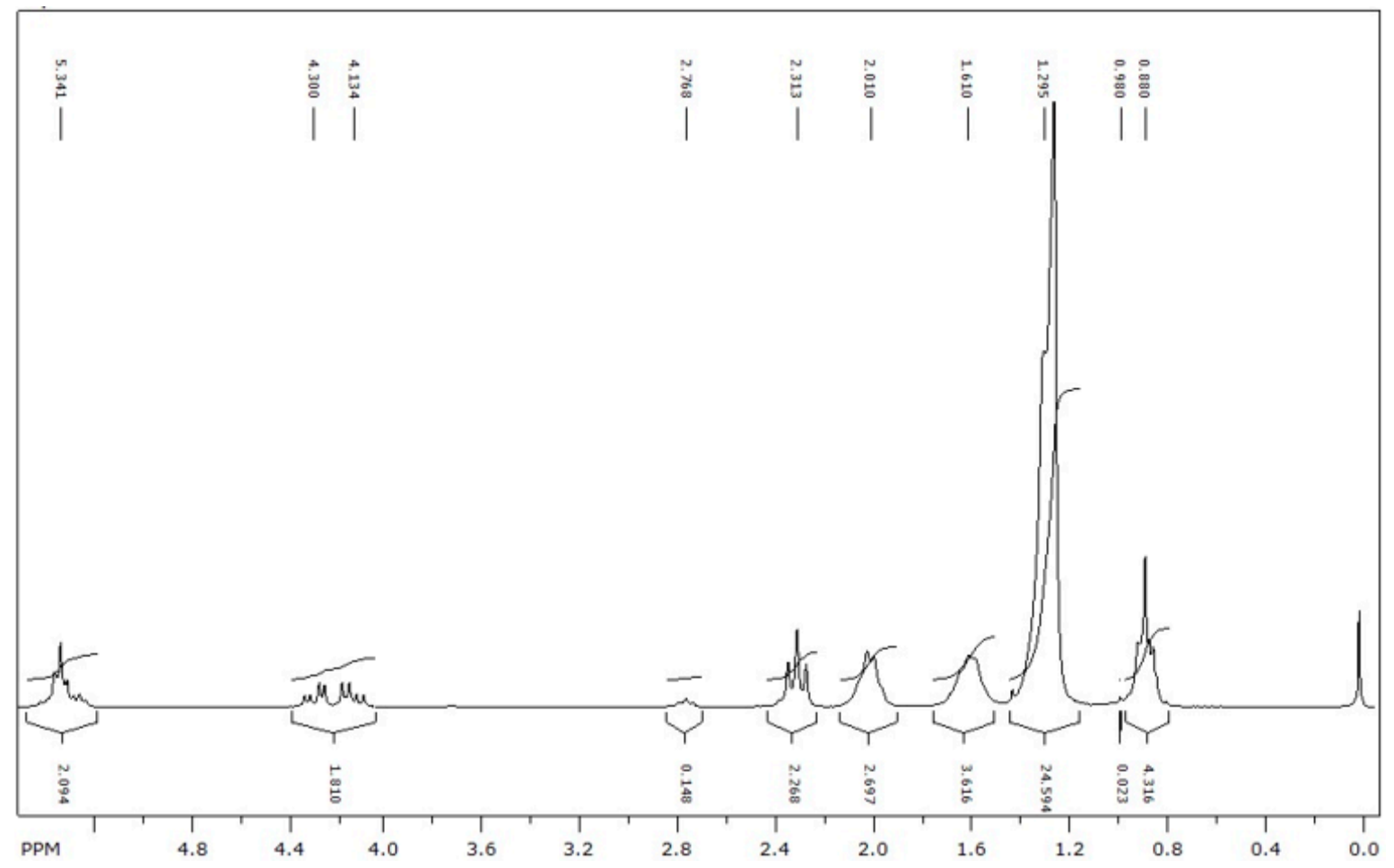

Figure S4. Buriti (Mauritia flexuosa)

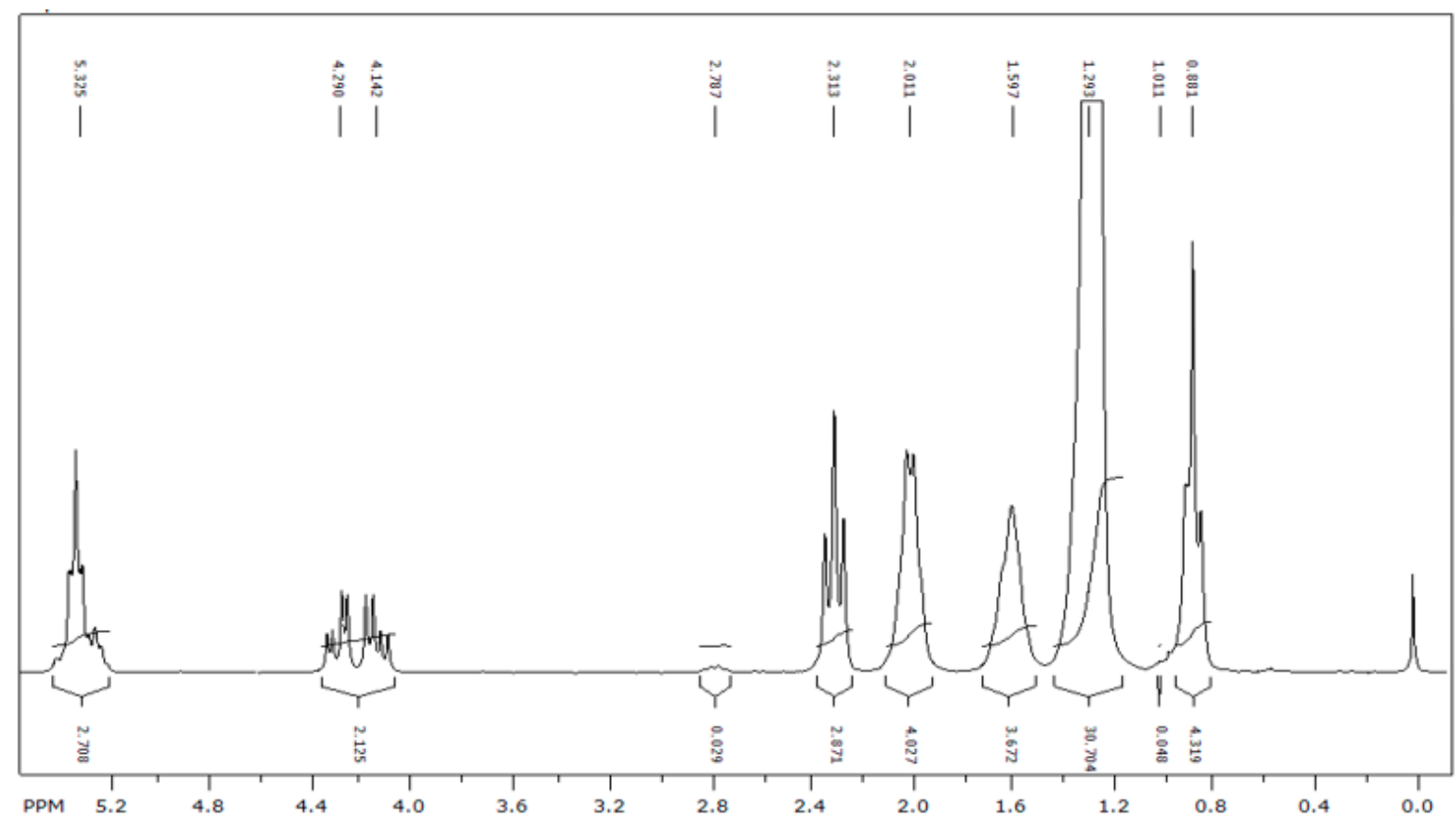


Figure S5. Buritirana (Mauritia aculeata)

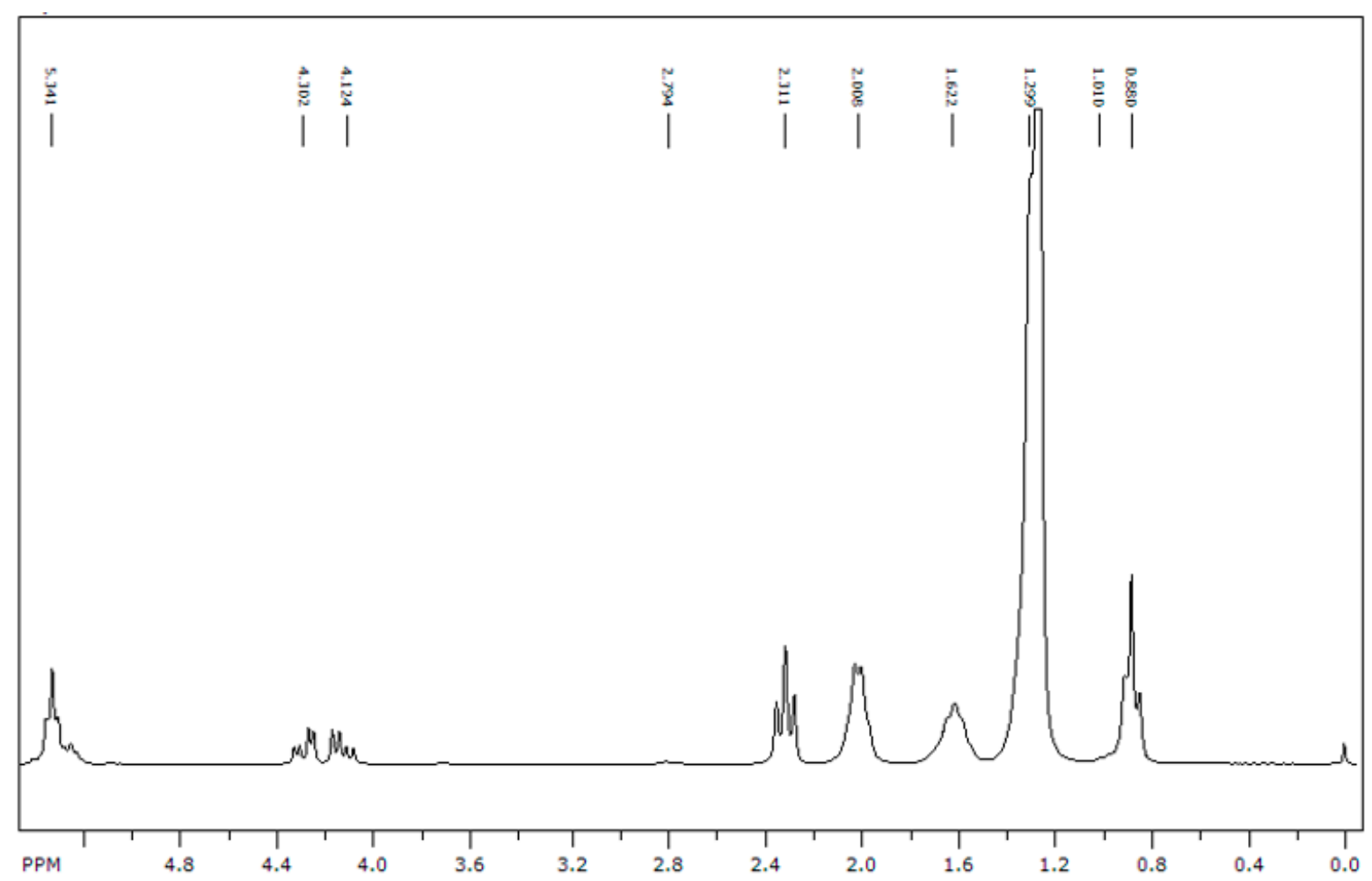

Figure S6. Yellow Murici (Byrsonima crassifolia)

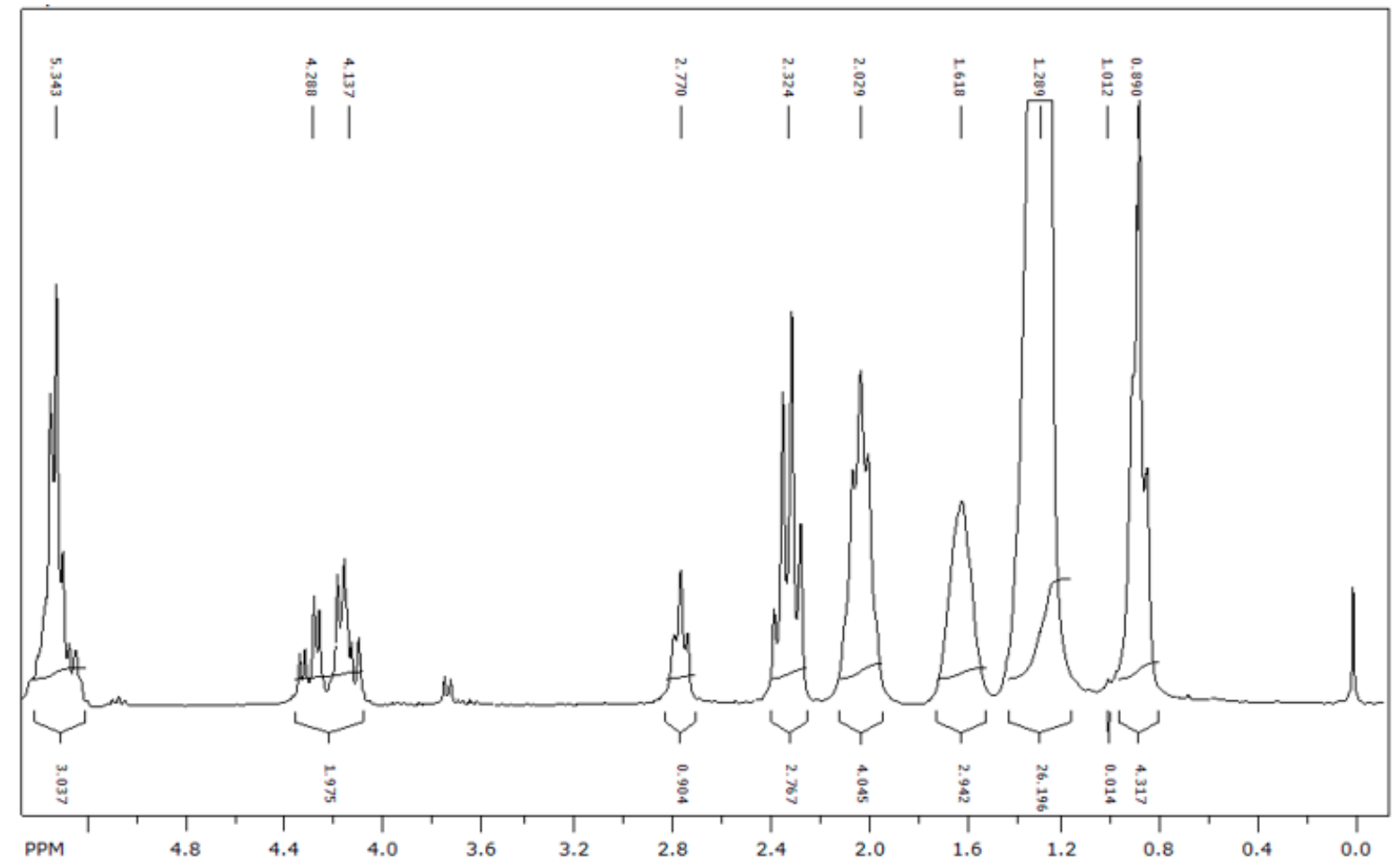


Figure S7. Red Murici (Byrsonima coccolobifolia)

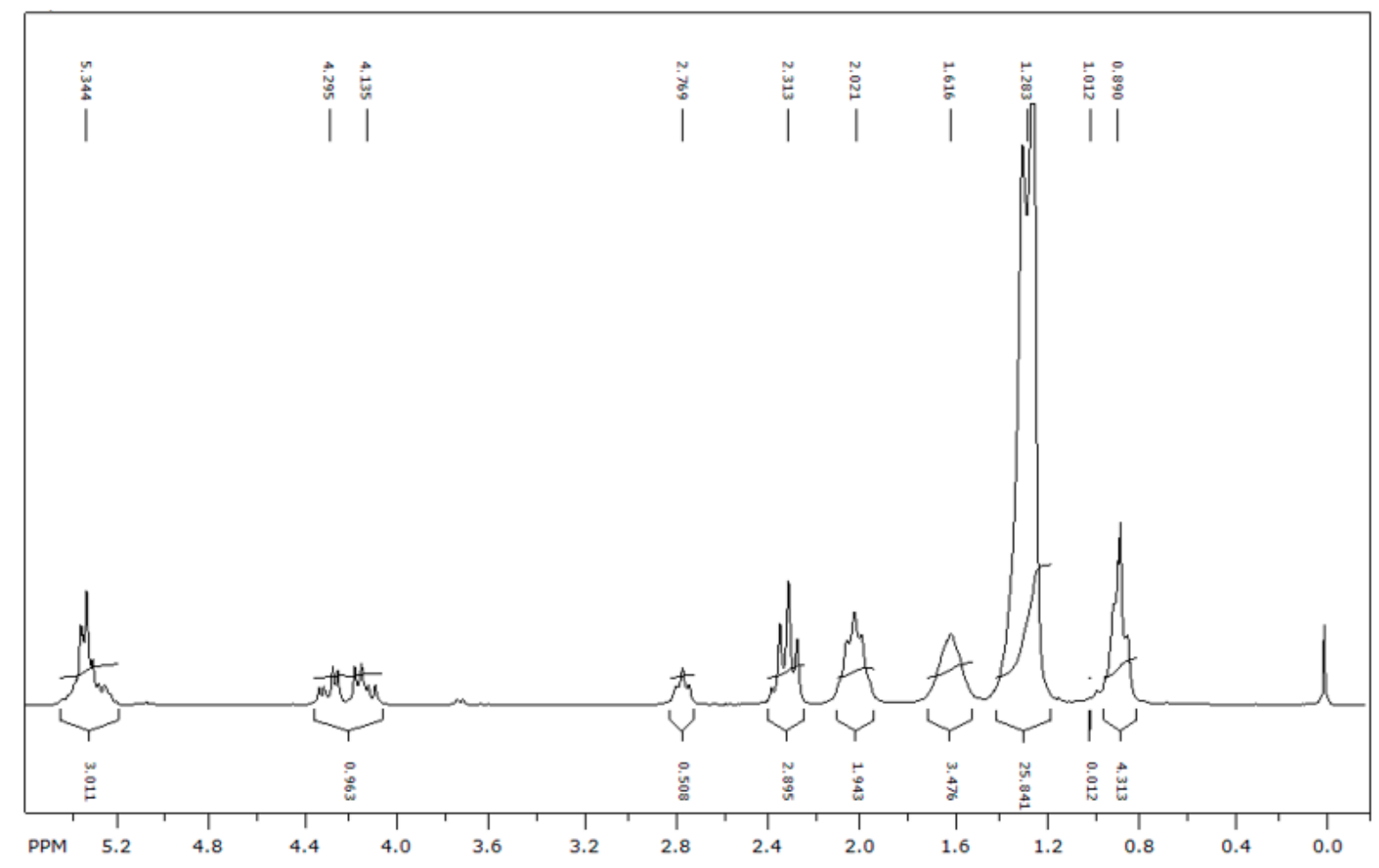

Figure S8. Red Pupunha (Bactris gasipaes)

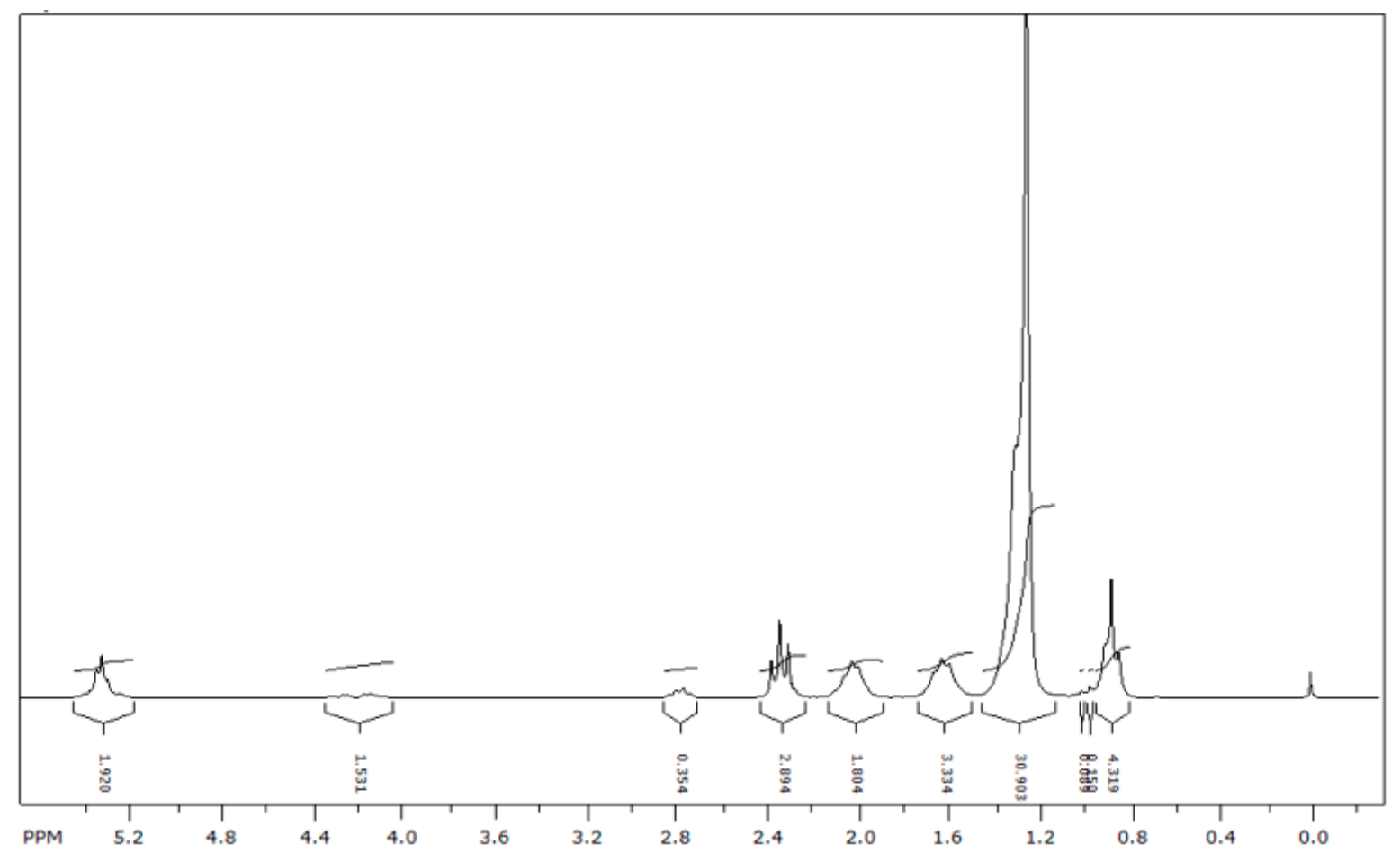


Figure S9. Yellow Pupunha (Bactris gasipaes)

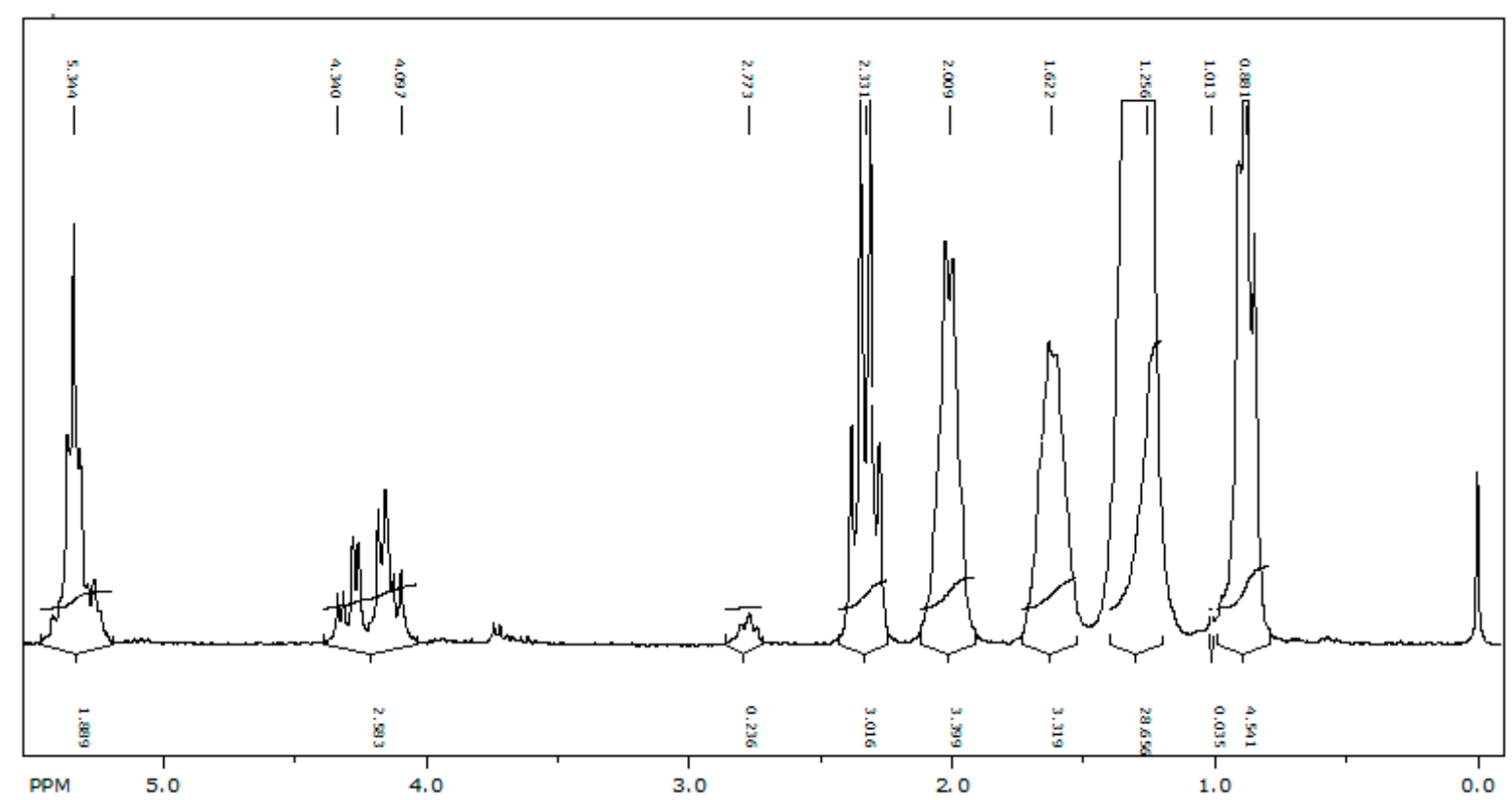

Figure S10. Tucumanzinho (Astrocaryum acaule)

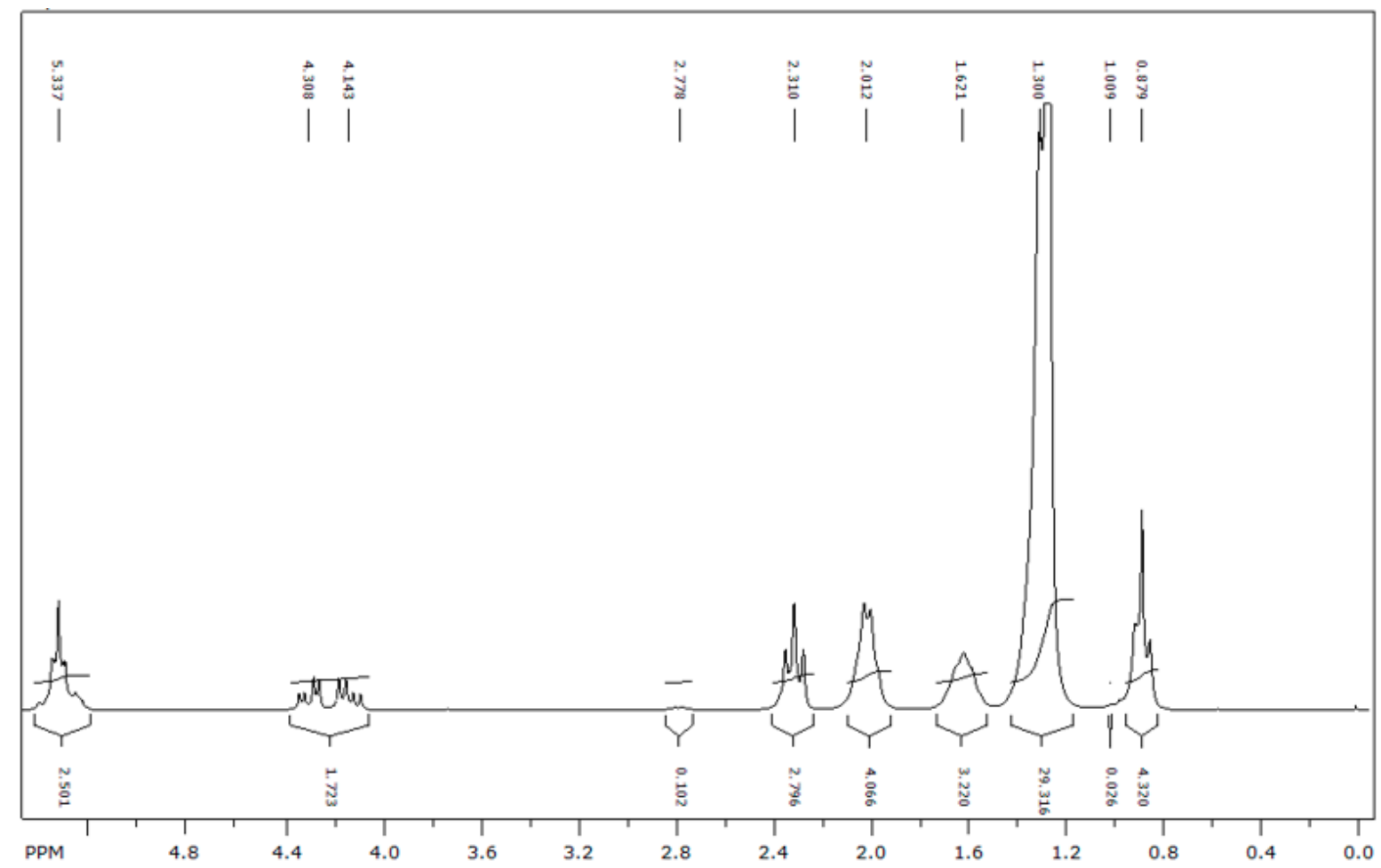

